\title{
Climate change and potential impacts on agriculture in Bhutan: a discussion of pertinent issues
}

Ngawang Chhogyel ${ }^{1,2^{*}}$ and Lalit Kumar ${ }^{1}$

\begin{abstract}
Background: The Himalayan country of Bhutan is typically an agrarian country with about $57 \%$ of the people depending on agriculture. However, farming has been constrained by the mountainous topography and rapid changes in environmental variabilities. With climate change, agricultural production and food security is likely to face one of the biggest challenges of the twenty-first century. The country has already been experiencing some impacts of climate change, such as crop loss to unusual outbreaks of diseases and pests, erratic rainfalls, windstorms, hail storms, droughts, flash floods and landslides annually.

Results: In 1996, rice farmers in high-altitude areas were devastated with 80-90\% crop loss to blast disease. Turcicum leaf blight of maize in 2007 damaged more than 50\% of the farmers' harvest. Also, in 2008, a severe windstorm flattened all maize crops belonging to hundreds of households. These were some gruesome reminders of the impacts of climate change that continues to threaten farming in Bhutan. The current agricultural practices are highly vulnerable to the impacts of climate change due to their total dependence on monsoon rains and shorter growing periods. The mountainous topography makes the country more vulnerable due to large climatic swings in the mountainous ecosystem. Field evidences have also shown that shifts in cropping pattern are taking place across agroecologies, thus indicating that farming in Bhutan is quite stressed. Further, climate modelling outputs have projected that there is likely to be marked changes in the pattern of precipitation and upward trend in temperatures.

Conclusion: In the mountainous topography of Bhutan, food production is a challenge and the impacts of climate change are likely to add to the burdens of farming. Since climate change impacts are already being felt, it is of paramount importance to focus on research works to understand and mitigate the impacts. The information generated from this study could contribute to both short- and long-term planning and policy development works related to food security and climate change in the near future.
\end{abstract}

Keywords: Bhutan, Agriculture, Climate change, Impacts, Food security, Vulnerability

\section{Background}

The Himalayan Kingdom of Bhutan is a land-locked country bordered by China in the North and India from the south, east and west. The country is broadly divided into six agroecological zones and experiences four seasons (Spring, Summer, Autumn and Winter). Agriculture is the main occupation of the Bhutanese people who generally undertake subsistence farming. The labour force

\footnotetext{
*Correspondence: nchhogye@myune.edu.au

${ }^{1}$ University of New England, Armidale, NSW, Australia

Full list of author information is available at the end of the article
}

survey report of 2016 showed that $57.20 \%$ of the Bhutanese population depend on agriculture [1]. According to the National Accounts Statistics 2017, the agriculture sector was the highest contributor to the national economy with $16.52 \%$, followed by construction industry and hydropower at $16.28 \%$ and $13.38 \%$, respectively [2]. This showed that Bhutan is an agrarian country that is totally dependent on biophysical factors and highly vulnerable to the impacts of climate change. The country's climatic and altitudinal variability allows cultivation of many crops, including year-round production. The main 
cereal crops cultivated by the farmers include rice, maize, wheat, barley, buckwheat and millet, with total production of 176,766 $\mathrm{t}$ in 2016 [3]. Among the fruit crops, the two most important ones are apples and oranges, and farmers cultivate almost all kinds of vegetable crops due to the large climatic variability across the agroecological zones. However, the country continues to import close to $30 \%$ of its food from outside, mostly from India. In order to improve its food self-sufficiency status, the three renewable natural resources (RNR) sectors (agriculture, forestry and livestock) under the Ministry of Agriculture and Forests (MoAF) have been putting in greater efforts to increase domestic production. In the last decade, the country has seen an increasing trend in food production and, currently, many initiatives and technical interventions are being introduced to contribute to the National Food Security Programme. According to agriculture statistics, there has been a steady increase in crop production from a low of 131,338 $\mathrm{t}$ in 2013 to $176,766 \mathrm{t}$ in 2016 [3]. The livestock production was $92,213 \mathrm{t}$ in 2012 but had spiked to $99,875 \mathrm{t}$ in 2014, which is an increase of $8 \%$ [4].

The country's total geographical size is $38,394 \mathrm{~km}^{2}$, of which cultivable land accounts for just $2.93 \%$ of its entire area [5]. This shows that the country has a limited cultivable land due to the geographical and topographic features. Further, farming in a mountainous ecosystem is challenged by inherently low soil fertility coupled with cold stress and frequent weather swings. Mountainous ecosystems are characterized by frequent extreme weather events and natural catastrophes [6], thus making it one of the most sensitive ecosystems of the world. With climate change, increasing agricultural production in Bhutan is going to be an uphill task if greater efforts and investments are not made in the research and development of climate resilient farming technologies. Crop productivity is directly related to the biophysical factors such as soil, ambient environmental conditions [temperature, solar radiation, moisture, carbon dioxide $\left.\left(\mathrm{CO}_{2}\right)\right]$, pests and diseases, and genetic potential of a particular variety. Researches have shown that weather and climate are the most serious environmental threats and have large influence on agricultural productivity $[7,8]$. Of late, Bhutan has been witnessing series of climate change impacts, such as erosion of fertile land caused by glacial lake outburst floods (GLOF) that have posed serious threat to people and property [9], emergence of new diseases and pests, increased frequencies of crop damaged by wildlife, and drought and drying of irrigation water sources [10]. This calls for enhanced research and development (R\&D) in agriculture, specially focusing on the development of climate resilient technologies. In recent years, the department of agriculture has made commendable strides in the introduction and promotion of climate smart agriculture as one of the priorities to adapt to changing climate. A number of drought-tolerant crop varieties have been developed and released for promotion across the agroecologies. There have also been breakthroughs in the development and release of higher yielding and disease-resistant crop varieties in rice, maize and wheat. The government is also advocating on crop diversification, dryland cropping, water harvesting and promotion of agroforestry and land management [11]. There have also been major shifts in agronomic practices and water management, such as site-specific nutrient management, organic farming, irrigation, nutrient dense crops and short-duration crops. As the country moves forward, it warrants a thorough review of the current practices and issues. As climate change is already happening, it is imperative that we take stock of how it is related to the country's agriculture. Thus, this paper provides an overview of Bhutan's subsistence farming, achievements, climate variables, challenges and potential impacts of climate change on the agriculture sector.

\section{Results and discussion Changes in climate variables}

Warming of the climate system is unequivocal, and new evidences show that changing weather and climate extremes have become quite common [12]. The weather patterns are getting unpredictable with increasing variability in the frequency, intensity and timing of monsoon. This could be disastrous for Bhutan as it is characterized by substantial variations in climate conditions due to dramatic changes in topography and altitude over a smaller area [13]. This will increase the country's vulnerability to the changing weather and climate. Such variations are also partly due to the country's location at the periphery of both tropical circulation in the north and Asian monsoon in the south [14]. Climatically, Bhutan is divided into six agroecological zones, which range between elevations of 150 to $4600 \mathrm{~m}$ above mean sea level (Table 1).

An analysis of the country's mean temperature and precipitations shows that the trend is increasing [14]. Such a trend matches with the findings of the Intergovernmental Panel on Climate Change (IPCC) which, unequivocally, reported rising global land and ocean temperature by $0.85{ }^{\circ} \mathrm{C}$ over the period 1880-2012 [12]. These changes are in line with the findings of the fourth assessment report of IPCC [16] which reported an average global temperature increase of $0.74{ }^{\circ} \mathrm{C}$ in the last hundred years. Therefore, more frequent extreme weather events are likely to occur with increasing temperature in the near future. Climate modelling studies on Bhutan have projected drastic changes in the mean temperature and precipitation, which have dictated changes in crop 
Table 1 The six agroecological zone of Bhutan. Source: Adapted from MoA [15]

\begin{tabular}{|c|c|c|c|c|c|c|}
\hline \multirow[t]{2}{*}{ Agroecological zones } & \multirow[t]{2}{*}{ Altitude (m) } & \multicolumn{3}{|c|}{ Temperature $\left({ }^{\circ} \mathrm{C}\right)$} & \multirow[t]{2}{*}{ Rainfall (mm year ${ }^{-1}$ ) } & \multirow[t]{2}{*}{ Remarks } \\
\hline & & Monthly (max) & Monthly (min) & Annual mean & & \\
\hline Wet subtropical & $150-600$ & 34.60 & 11.60 & 23.60 & $2500-5500$ & Agriculture predominant \\
\hline Humid subtropical & $600-1200$ & 33.00 & 4.60 & 19.50 & $1200-2500$ & Agriculture predominant \\
\hline Dry subtropical & $1200-1800$ & 28.70 & 3.00 & 17.20 & $850-1200$ & Agriculture predominant \\
\hline Warm temperate & $1800-2600$ & 26.30 & 0.10 & 12.50 & $850-1200$ & Agriculture predominant \\
\hline Cool temperate & $2600-3600$ & 22.30 & 0.10 & 9.90 & $650-850$ & Agriculture marginal \\
\hline Alpine & $3600-4600$ & 12.00 & -0.90 & 5.50 & $<650$ & Livestock predominant \\
\hline
\end{tabular}

suitability [17]. Simulated projections for Bhutan as well as for South Asia, where Bhutan is situated, have shown rising trends in temperature and precipitation in both winter and summer with large anomalies in monsoon (Table 2). The simulation models have predicted mean summer and winter temperature increases of $2.8^{\circ} \mathrm{C}$ and $2.1{ }^{\circ} \mathrm{C}$, respectively, over $2040-2069$ [13]. Further, simulation models of IPCC [12] for South Asia have indicated changes in precipitation patterns with rising mean temperature of $1.3-3.5{ }^{\circ} \mathrm{C}$ over 2100 . In terms of precipitation patterns, winter rains are going to be lesser, while it is projected to increase in summer. Other studies have also reported major changes in temperature and precipitation in the range of $2.9-4.3{ }^{\circ} \mathrm{C}$ and $13-34 \%$, respectively, using different models and scenarios [18]. IPCC [12] also predicted a high likelihood of extreme weather events, such as heavy precipitations accompanied by high intensity and frequency, droughts, heat waves and increased cyclone activities (Table 3). These predictions corroborate the projections provided by the International Centre for Integrated Mountain Development (ICIMOD) for the Eastern Himalayan region [18]. According to ICIMOD, a significant warming has been observed in places situated at higher elevations than lower ones. Such findings would hold true for Bhutan that has experienced fast receding of glaciers in the mountains [19]. Glacier retreat was also reported in other parts of the Himalayas [20] that include Bhutan. Various other studies have reported reduced frequency and depth of snow [21,22] which is an embodiment of reduced glaciers that forms the country's water tower. The future outlook of climate and glacier scenarios projected by Rupper, Schaefer [23] warned that Bhutan would lose large glacierized areas with corresponding reduction in glacier meltwater flux. These findings provide conclusive proof of the negative impacts of climate change on hydrology and agriculture in Bhutan.

\section{Crop production and technologies}

Agricultural development in Bhutan commenced with the opening of Bhutan's door to the outside world and planned development in 1961. However, organized agricultural research in Bhutan started only in early 1980s with the primary mandate of solving farmers' immediate needs [24-26]. Since then, the country has seen tremendous changes in farming methods, cropping patterns and crop production technologies. The agricultural research and development sector has been able to develop and promote many higher yielding varieties of crops. The main food crops include rice, maize, wheat and barley [3]. Farmers grow almost all kinds of vegetable crops, ranging from subtropical to temperate crops. Also, in fruits and nuts, Bhutan grows subtropical to temperate types, with

Table 2 Simulated changes in climate variables for Bhutan and South Asia. Source: Adapted from National Environment Commission (NEC) [13] and IPCC [12]

\begin{tabular}{|c|c|c|}
\hline \multirow[t]{2}{*}{ Parameters } & \multicolumn{2}{|l|}{ Simulated changes } \\
\hline & Projections for Bhutan & Projections for South Asia \\
\hline Mean annual temperature & Increase by $2.1-2.4^{\circ} \mathrm{C}$ over $2040-2069$ & Increase by $1.3-3.5^{\circ} \mathrm{C}$ in 2100 \\
\hline Mean summer temperature & Increase by $2.8^{\circ} \mathrm{C}$ over $2040-2069$ & Increase by $2^{\circ} \mathrm{C}$ in 2100 \\
\hline Mean winter temperature & Increase by $2.1^{\circ} \mathrm{C}$ over $2040-2069$ & Increase by $2.55^{\circ} \mathrm{C}$ in 2100 \\
\hline Mean annual precipitation & $\begin{array}{l}\text { Increase by } 20 \% \text { over } 2040-2069, \text { wetter monsoon and } \\
\text { drier winter }\end{array}$ & Decrease by 3\% (min) and increase by 37\% (max) in 2100 \\
\hline Monsoon mean total precipitation & $\begin{array}{l}\text { Increase by about 350-450 mm/season from } 1980 \text { to } \\
2069\end{array}$ & Decrease by $7 \%(\min )$ and increase by 37\% (max) in 2100 \\
\hline Winter mean total precipitation & Decrease by about 5 mm/season from 1980 to 2069 & Decrease by $14 \%$ (min) and increase by $28 \%$ (max) \\
\hline
\end{tabular}


Table 3 Projections of extreme weather events and their impacts. Source: Adapted from IPCC [12] and NEC [13]

\begin{tabular}{llll}
\hline SI. no. & Extreme weather events & Likelihood of further changes & Relevance for Bhutan \\
\hline 1 & $\begin{array}{c}\text { Fewer days of warmer cold days and nights over } \\
\text { most areas }\end{array}$ & Likely to virtually certain & Could change crop phenology and yield \\
2 & $\begin{array}{c}\text { Warmer and/or more frequent hot days and nights } \\
\text { over most areas }\end{array}$ & Likely to virtually certain & Could directly affect crop yield and water productivity \\
3 & $\begin{array}{c}\text { Heavy precipitation events (increased frequency, } \\
\text { intensity, amount) }\end{array}$ & Likely to very likely & $\begin{array}{c}\text { Could lead to increased flash floods, erosion and crop } \\
\text { loss }\end{array}$ \\
4 & Increases in intensity and duration of drought & Likely & Will have direct effect on crop yield \\
5 & Increases in intense tropical cyclone activity & Likely & Increased crop damages/loss \\
\hline
\end{tabular}

Table 4 List of released crop varieties grown by the farmers in Bhutan. Source: Adapted from DoA [28]

\begin{tabular}{llrl}
\hline SI. no. & Crops & \multicolumn{2}{l}{ Varieties } \\
\hline 1 & Rice & 23 & Including upland varieties \\
2 & Maize & 4 & Across ecologies \\
3 & Other cereals & 5 & Wheat and millet \\
4 & Mustard & 5 & For low and mid-altitudes \\
5 & Soybean & 4 & For low and mid-altitude \\
6 & Vegetables & 84 & $\begin{array}{c}\text { Includes varieties of 30 types of } \\
\text { vegetables } \\
\text { Includes varieties of 26 types of fruit } \\
7\end{array}$ \\
Frops
\end{tabular}

the most popular ones being apples, oranges, walnuts and stone fruits [3]. Nowadays, farmers also grow many new varieties of crops in rice, maize, other cereals, vegetables, fruits and nuts, oilseeds and legumes (Table 4). On the production front, except for other cereals (wheat, barley, buckwheat and millet), rice and maize show an increasing trend with steady increase in yield from 2009 to 2016 (Fig. 1). Similarly, there are also some notable achievements in fruit and vegetable production (Fig. 2). On a smaller scale, the country also exports some agricultural products, of which the top three export crops are potatoes, mandarin and apples, including some nonwood forest products $[10,27]$. While fruit production is increasing, the department is also putting greater effort in value addition and post-harvest technologies. The Department of Agriculture (DoA) is also focussing on the sustainable land management programme [28] which is crucial from the view point of Bhutan's limited agricultural land and its topography. Bhutan needs to protect its land resources from degradation and soil losses, which is an impending issue in the mountainous ecosystem.

In order to reduce drudgery of farming and for improving labour efficiency, farm mechanization is one of the priorities of the DoA $[29,30]$. Given the topographic factors and small farm sizes, large-scale and complete mechanization is impossible. But every possible effort has been made to increase the level of mechanization through a nationwide mechanization drive [29]. Where possible, the farm mechanisation programme tries to at least partially mechanize farming activities through the use of smaller machines. Farmers' access to machineries has been ensured through state-owned machinery hiring services and allotment of machineries to the local government bodies. Farmer-friendly machines, such as mini-power tillers and reapers, have been made available at subsidized rates. While there are no nationwide studies undertaken to assess the level and impacts of mechanization, informal sample field reports have indicated positive trends.

\section{Land use and farming system}

Bhutan is located in the southern slopes of the Eastern Himalayas between the latitudes $26^{\circ} 42^{\prime} \mathrm{N}$ and $28^{\circ} 14^{\prime}$ $\mathrm{N}$ and longitudes $88^{\circ} 44^{\prime} \mathrm{E}$ and $92^{\circ} 07^{\prime} \mathrm{E}$. Of the total geographical area of $38,394 \mathrm{~km}^{2}, 70.47 \%$ is under forest cover. Shrubs occupy $10.43 \%$, snow $7.44 \%$, bare rocky areas $3.20 \%$, and meadows constitute $4.10 \%$ with cultivated area of just $2.93 \%$ [5]. It is a country with good forest cover and is characterized by highly rugged mountainous agroecosystem where farmlands are scattered. Farming is limited to the river valleys and are generally seen as small parcels on slopes (Fig. 3). The generalized land use categories are kamzhing (dryland), chuzhing (terraced rice fields) and horticulture (orchards and plantation crops) with per cent land coverage of $61.90 \%, 27.86 \%$ and $10.24 \%$ of the agricultural land, respectively [5]. Bhutanese farmers, in general, are small holders who practice sustainable integrated and subsistence agricultural farming system [31]. The average land holding of each farmer is just 1.4 ha [4], and they grow a variety of crops under different farming practices, including rearing of livestock to meet their household food security. There are also marked variations in farming systems and cropping patterns across the country. However, in general, the farmers mostly practice rice-, maize- and potato-based farming 


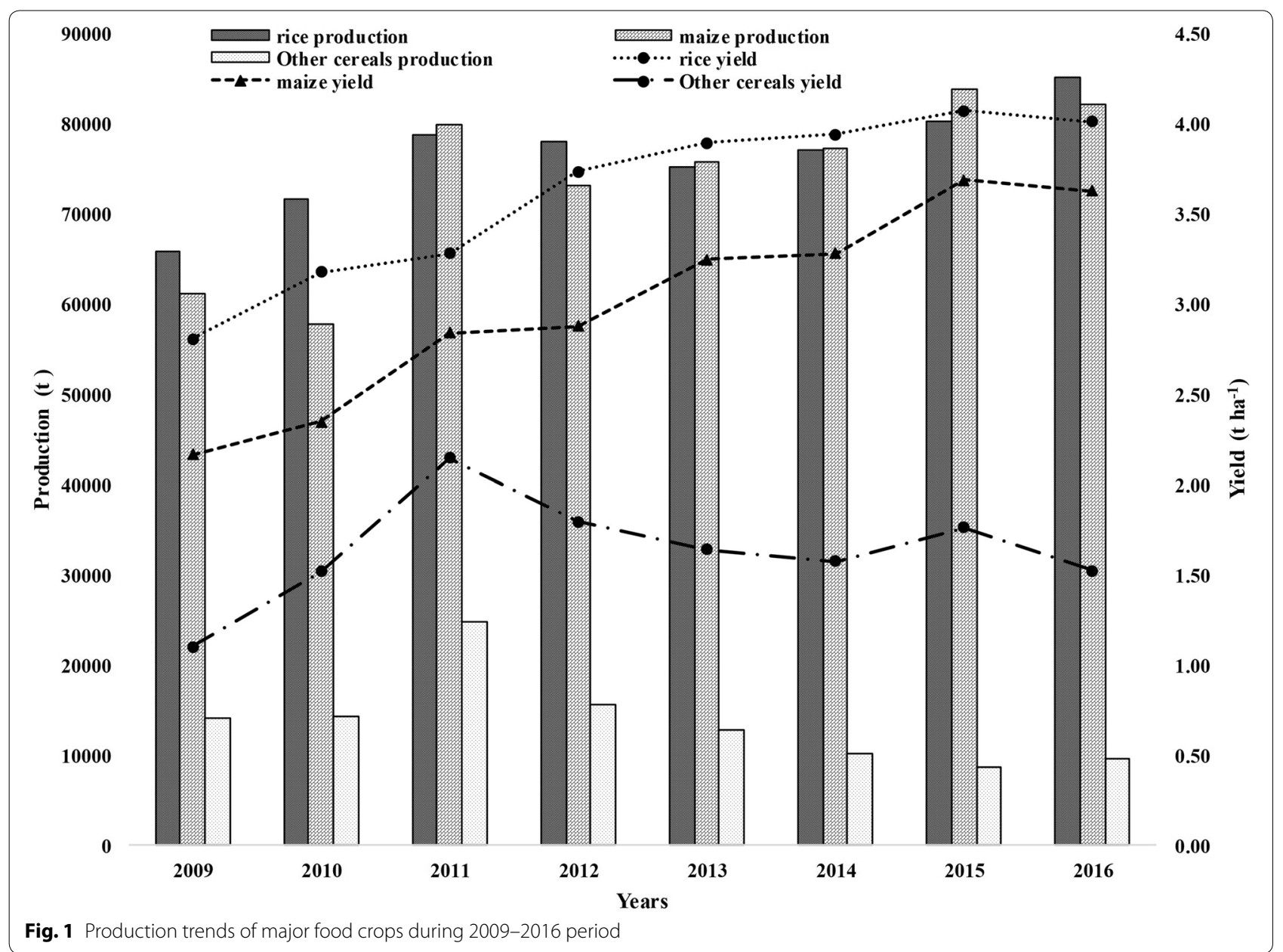

Fig. 1 Production trends of major food crops during 2009-2016 period

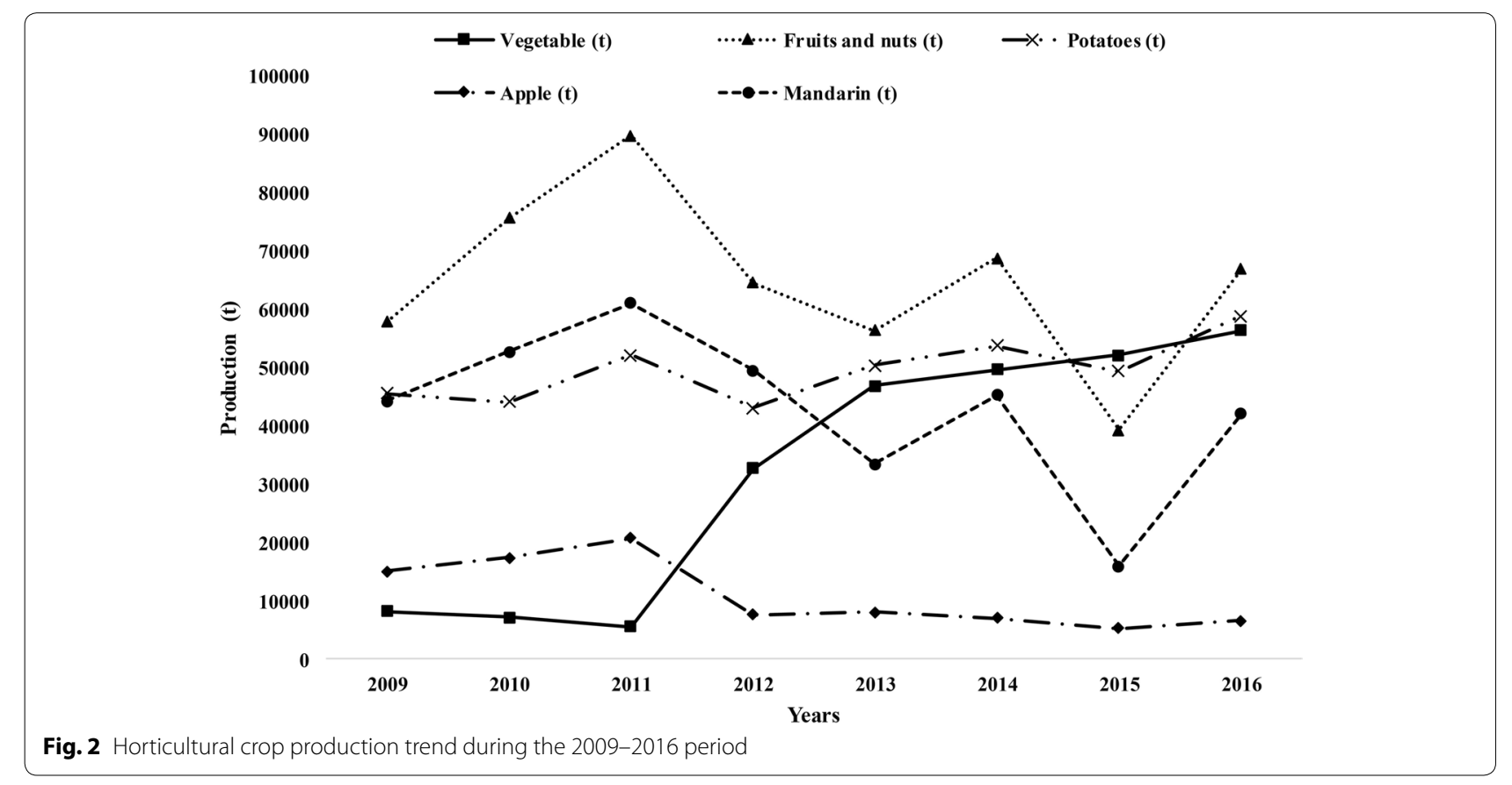




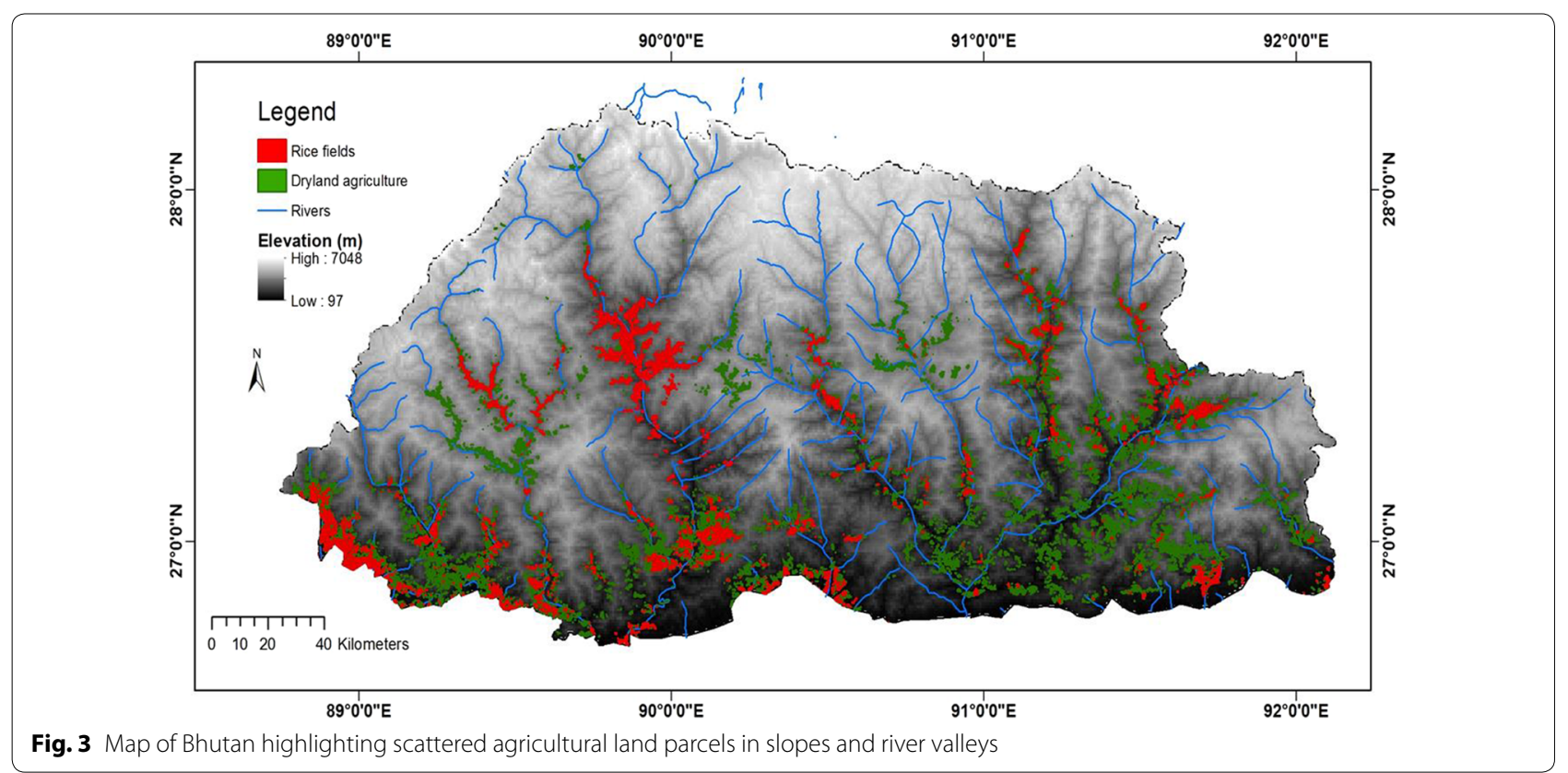

system with multiple crop combinations, including agroforestry and livestock integration (Table 5). Such a multiple cropping system offers best opportunities to the small holder farmers to shift from subsistence to intensive farming for food and nutritional security [32]. Such an integration is also important to exploit maximum benefits as well as minimize the risk of farming enterprise while enhancing the productivity of a farmland [33]. Farmers also obtain substantial benefit from the collection and sale of non-wood forest products for sustaining their livelihood [4, 27]. The department of forests and park services also supports and promotes private and community forests. Records say that farmers in Bhutan manage 600 community forests and 627 private forests spanning over 66,934 and 841 acres, respectively [4]. Such practices not only help in sustainable management of forestry resources but also provide income and employment to the rural communities.

\section{Climate change and its potential impact}

The impacts of climate change are one of the greatest challenges the country is facing today and would

Table 5 Generalized farming systems prevalent in Bhutan

\begin{tabular}{lll}
\hline Farming system & Crop combinations & Remarks \\
\hline Rice based & Rice-wheat & Common in mid- and low altitude \\
& Rice-maize & Common in low altitude \\
& Rice-mustard & Common in mid-altitudes \\
& Rice-potato & Common in high and mid-altitudes \\
Maize based & Rice-vegetables & Practised throughout the country \\
& Maize-wheat & Common in mid-altitudes of central and \\
& Maize-barley & eastern regions \\
& Maize-mustard & Common in high and mid-altitudes \\
& Maize-potatoes & Common in low and mid-altitudes \\
Potato based & Potato-mustard & Common in Eastern Bhutan \\
& Potato-wheat/barley & Common in high altitudes \\
Agroforestry & Potato-turnip & Common in high altitudes \\
& Crop-fodder-animals & Popular in high altitude \\
& Crop-fodder-trees-animals & Common throughout the altitude range \\
\hline
\end{tabular}


continue to be so in the near future. The impacts and changes are mainly driven by the increased global emissions of greenhouse gases. However, Bhutan is considered as a carbon-neutral or a carbon-negative country [34]. Nonetheless, the country is bearing the brunt of emissions caused by larger global economies of the world. The impacts of climate change have started to pose a serious threat to agriculture, biodiversity and livelihood of the Bhutanese people. Of late, Bhutan has been witnessing frequent extreme weather events, causing widespread damages to crops and livelihoods of the people. Evidences of climate change impacts compiled from various sources show convening climate change impacts on agriculture (Table 6).

The agricultural production management system of Bhutan does not show a resilient picture. A brief analysis of Bhutan's agricultural system and its potential impacts to climate change is discussed in the contexts of the three broad land use categories in subsequent paragraphs.

\section{Climate change and rice farming}

In Bhutan, terraced rice cultivation is commonly referred to as wetland farming, which constitutes $27.86 \%$ of the country's cultivable land [5]. Rice is known to require more water than any other crop [38, 39], thus making it the most vulnerable and highly dependent on climatic parameters, such as monsoon rains and temperature. In Bhutan, rice is grown under irrigated, rainfed and upland ecosystems. Under both irrigated and rainfed systems, rice farming stands out to be highly sensitive to climate change since it requires large quantities of water. In the case of irrigated system, rice cultivation is mostly dependent on monsoon charged spring waters and streams fed by glacier melts. Slight delays or changes in pattern of rain will directly impact both availability and amount of irrigation water. In rainfed rice, crop cultivation is totally dependent on monsoon rain which make it highly vulnerable and sensitive to the changing patterns of monsoon. Simulation modelling works for the Himalayan glaciers that included Bhutan and Nepal showed substantial reduction in the fraction of precipitation as snow despite an overall increase in precipitation in the region [40]. Further, linear regression models have confirmed changes in temperature and precipitation patterns across the high-altitude zones of Bhutan [41]. This is going to have a direct effect on the snow and glacial-fed rivers and streams which are the primary sources of irrigation water. While there are water-saving technologies in rice, adoption has been an issue thus far. A more climate resilient form of rice cultivation alternative is upland rice, but it is limited to smaller areas in Eastern and Central Bhutan.

In recent years, rice production has been beset with other issues such as appearance of new diseases and insect pests. Though there have been breakthroughs in the breeding and release of eight blast-resistant varieties after the rice blast epidemic of 1995-1996 (Table 7), their resistance has been reported to be breaking down.

Rice intensification through double cropping is not possible due to cold stress, shorter cropping periods and unavailability of short-duration varieties. Rice double cropping would require varieties that would fit into the shorter growing period. Rice in Bhutan's condition takes longer to mature due to cold stress and has a shorter window period for cropping. Rising temperatures due to climate change might increase the crop-growing season, but the combined effect of temperature increases and changing rainfall pattern would probably counteract the gains in cropping duration. Thus, the country might not benefit from climate change since it is going to be

Table 6 Evidences of climate change impacts being felt in Bhutan

\begin{tabular}{|c|c|c|c|}
\hline Extreme weather events & Year & Remarks & $\begin{array}{l}\text { Information } \\
\text { sources }\end{array}$ \\
\hline Glacial lake outburst (GLOF) flash flood & 1994 & Damaged 965 acre of agricultural land & {$[10,13]$} \\
\hline Rice blast epidemic & 1996 & $80-90 \%$ crop loss in high altitudes & {$[35,36]$} \\
\hline High-intensity monsoon rain, nationwide & 2004 & Damaged 39 irrigation channels & {$[13,36]$} \\
\hline Northern corn blight & 2007 & $>50 \%$ crop loss in high altitudes & {$[32,35]$} \\
\hline Unusual windstorm & 2008 & Damaged maize crops of 320 hhs in Eastern Bhutan & {$[13]$} \\
\hline Cyclone Aila/flash flood & 2009 & $>100$ acre land washed away & {$[35,36]$} \\
\hline Flash flood and landslides & 2010 & Affected 809 acre of land, damaged irrigation channels & {$[13,35]$} \\
\hline Hailstorm in Punakha & 2012 & $30-40 \%$ rice crop damaged & {$[35]$} \\
\hline High-intensity rain/windstorm & 2013 & $\begin{array}{l}>100 \text { acre maize crop damaged, erosion and damaged irrigation } \\
\text { structures }\end{array}$ & {$[10]$} \\
\hline Hailstorm/flash flood & 2015 & $>100$ acre rice crop damaged & {$[37]$} \\
\hline High-intensity rain & 2016 & > 100 acre rice crop damaged & {$[37]$} \\
\hline
\end{tabular}


Table 7 List of locally bred blast-resistant varieties developed post-rice epidemic of 1995. Source: Adapted from Javier [42]

\begin{tabular}{lll}
\hline Sl. no. & Varieties & Agroecosystem \\
\hline 1 & Yusi rey Maap1 & High altitude \\
2 & Yusi rey Maap2 & High altitude \\
3 & Yusi rey Kaap1 & High altitude \\
4 & Yusi rey Kaap2 & High altitude \\
5 & Bajo Maap1 & Mid-altitude \\
6 & Bajo Maap2 & Mid-altitude \\
7 & Bajo Kaap1 & Mid-altitude \\
8 & Bajo Kaap2 & Mid-altitude \\
\hline
\end{tabular}

accompanied by erratic precipitation and high-intensity rains that would negatively affect farming.

Generally, Bhutan is projected to gain some areas in suitability towards the mid-altitude and northern regions under future climate scenarios [43]. However, expansion of cultivation areas is not going to make much difference due to limitations posed by the geographical terrain. More so, rice yield in the southern subtropical regions will be adversely affected by the heat waves, drought and changing patterns of precipitation. It has been reported that both rice yield and grain qualities were reduced under high temperature [44]. Similarly, there were studies confirming spikelet sterility due to high-temperature stress in rice which directly contribute to yield reduction [45]. All these climate-related issues signal a grim picture for the future of the rice sector in the country. Going by the IPPC's projected temperature rise of $2.0-4.8^{\circ} \mathrm{C}$ over 2046-2100 under worst scenario of representative concentration pathways (RCP) 8.5 [12], small holder farmers in South Asian regions will be devastated, leading to widespread hunger and famine [46].

\section{Climate change and dryland farming}

Dryland constitutes an important land use category that includes area under cereals, such as maize, wheat, barley, buckwheat and millet [4]. Together with rice, the dryland cereal crops are the main staple food crops of Bhutan; however, the potential impacts of climate change would make the situation worse by reducing yields and productions. Considering carbon fertilization effect of increased atmospheric $\mathrm{CO}_{2}$ for photosynthesis, some crop yield simulation models have shown positive contribution on the yield of dryland crops $[47,48]$. However, the combined effects of $\mathrm{CO}_{2}$ fertilization, changing patterns of precipitation and heat stress would likely have negative impacts on crop yields [49]. Research findings showed that changing seasonal temperature and precipitation accounted for global crop losses of about $40 \mathrm{Mt}$ of wheat, barley and maize in 2002 due to large yield reduction [50]. However, a study also indicated likely gains in suitability of crops in the mid- and high-altitude areas due to warming [51]. Nonetheless, such a climatic suitability gain might not translate to actual increased production areas for Bhutan owing to the country's topography and narrow crop-growing seasons due to wide variations in altitude and environmental conditions.

The dryland farming system is basically practised on upland mountain slopes which make it highly prone to the vagaries of climatic and weather events, such as soil erosion, land fragmentation and nutrient loss. Farmers' low land holdings and subsistence level of production make it even more sensitive to the impacts of climate change. Loss of traditional genetic resources has been reported in terms of both crop species and varieties [31], thus increasing vulnerability of Bhutan's farming to the climatic shocks. Loss of farm diversity and its vulnerability is evident from the steady decrease in area and production of dryland crops. According to agriculture statistics, area and production of the four main minor cereal crops continued to show a decreasing trend (Fig. 4). In the last 8 years, the total area and production in these crops decreased from about 22,126 ac and 15,662 $\mathrm{t}$ in 2012 to 16,310 ac and $9642 \mathrm{t}$ in 2016, respectively. For various reasons, such as climate change and socio-economic, many traditional varieties of crops are reported to be disappearing and replaced (Table 8). Some indigenous crops have disappeared due to diseases and pest incidences. In wheat, leaf and stripe rust diseases have been reported [52], while maize was devastated by Turcicum leaf blight in 2006-2007 [32, 35]. Though on a smaller scale but widely practised across the country, vegetable farming is competing on both wet land and dryland farming systems. With low returns from dryland farming, dryland crops are increasingly being converted to vegetable farming which is one of the intensively cultivated systems using conventional technologies. This is ecologically not healthy and is going to further stress the already limited land resources. Data compiled from the agriculture statistics [53] indicate that crop loss to extreme weather events was annually reported, and with climate change, the frequency and intensity of such issues would increase manifold. Projected high-intensity rain in summer and reduced rains in winters in the Himalayan regions [18] indicate massive erosions, crop damage as well as crop loss due to its direct effect on winter crops.

\section{Climate change and horticultural farming}

In the last 10 years, the horticulture industry has experienced worse scenarios of fruit loss to diseases and pests. The citrus industry has been devastated by the citrus greening, or the Huanglongbing (HLB) disease, since 


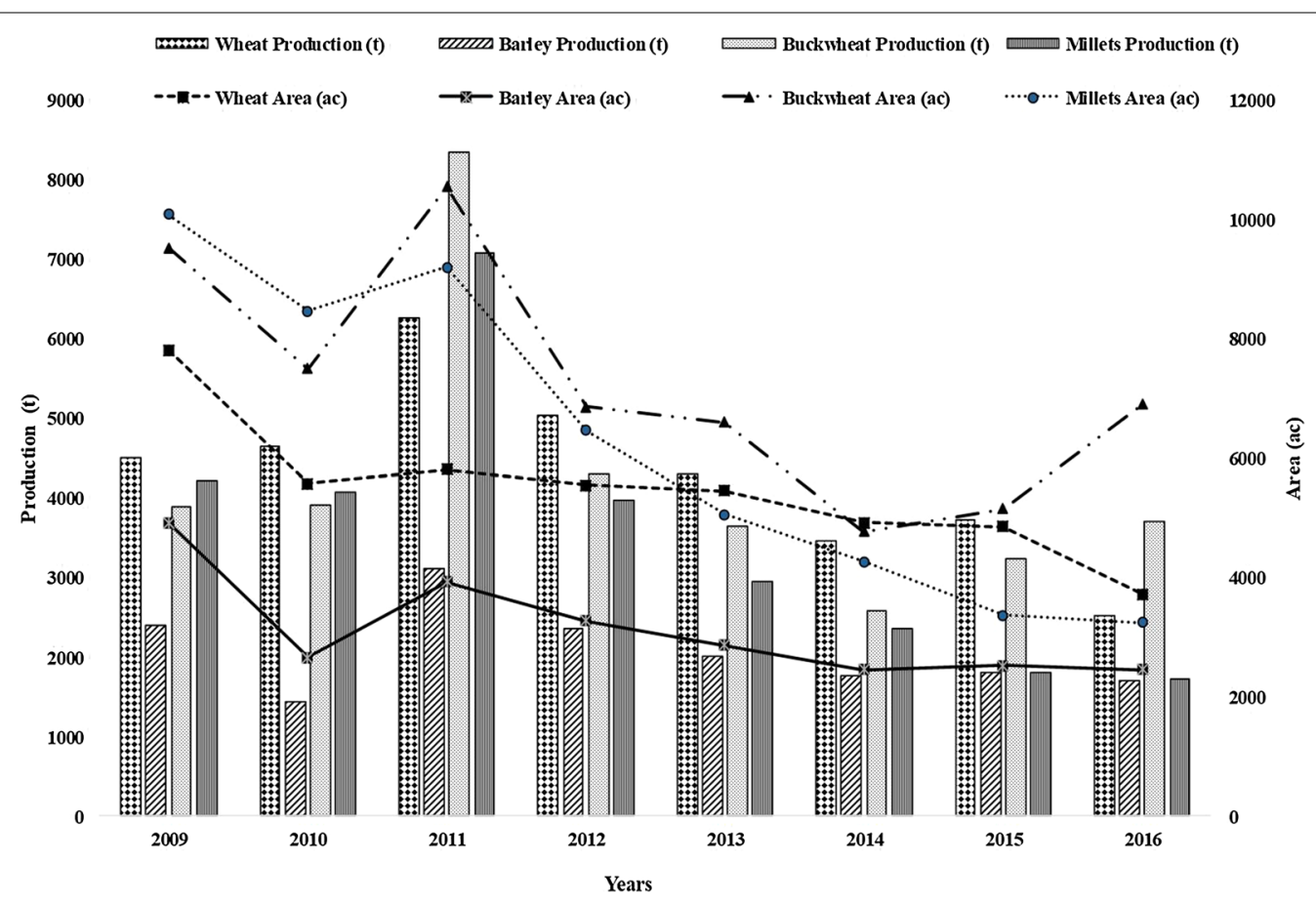

Fig. 4 Decreasing trend in area and production of minor cereals in Bhutan

Table 8 List of crops displaced by new crops in different districts of Bhutan. Source: Adapted from Katwal et al. [31]

\begin{tabular}{lll}
\hline Crops displaced & New crops & Districts \\
\hline Rice & Arecanut, cardamom, vegetables and fodders & Sarpang and Samtse \\
Maize & Ginger, arecanuts, citrus and vegetables & Sarpang, Samtse and Dagana \\
Wheat & Potatoes, vegetables and fodders & Sarpang, Samtse, T/Yangtse, \\
& & Dagana, Paro and Haa \\
Barley & Ginger, arecanut, citrus, vegetables and fodders & Paro, Haa, Dagana and T/Yangtse \\
Buckwheat & Potatoes, vegetables and fodders & Paro, Haa, Dagana and T/Yangtse \\
Millet & Vegetables, potatoes and fodders & Paro and Haa \\
\hline
\end{tabular}

2003 [54]. Further, citrus farmers are also struggling with the drop in fruit production caused by citrus fruit flies [55]. In the case of apple orchards, woolly aphids, brown rot, collar rots and apple scab diseases have been reported in almost all apple-growing northern districts [56]. Similarly, cardamom production has stagnated due to widespread wilt disease. Statistics show apple and mandarin production have started to decline (Fig. 2) which could be attributed to biotic and abiotic stresses [10]. Unlike field crops, fruit are highly vulnerable and sensitive to climate change mainly because of their longer duration for establishment [57]. While cultivation of fruits, such as pear, peaches and walnut, are reported to be picking up, their area and production is very low [10] and does not make much impact. Drought during flowering is very sensitive, and long dry spells make orchard farming very stressful.
Extreme weather, such as hail and windstorms, destroys the flower buds, fruits and shatters them, rendering the tree branches barren. Apple orchards in India have also experienced frequent incidences of hailstorms causing huge crop losses [58]. The report of increasing hurricane damages on citrus in the USA [59] highlights the susceptibility of fruit industries to the extreme weather events. All existing orchards in Bhutan are highly prone to such weather events, and the issue is going to get worst as warming continues in the twenty-first century.

Of late, intercropping of orchard soils with vegetables and fodder crops has also been observed to be getting popular, which increases the pressure on the orchard land resources. Owing to topography, plant height and nature of crops, fruit trees are more prone to risk factors, such as soil erosion, floods, hail, high-speed winds, 
nutrient mining and land slips. Another alarming issue with global warming is that of its dramatic effect on the chilling requirement of the temperate fruits [60]. This is likely to adversely impact production of fruits and nuts which are grown in temperate regions of the country. Studies have projected a decline in the winter chill which is crucial for many fruits and nuts in temperate countries [61]. The combined effects of insufficient chill requirement, drought, hailstorms, winds and changing patterns of rain will drastically reduce area and production fruits. Other than the fruit crops, climate change is also projected to devastate potato farming. Though potato cultivation is widespread in the country, the crop is rainfed and highly prone to weather factors. With changing monsoonal pattern and rising temperature, potato cultivation would decline drastically [17].

\section{Challenges and issues}

Farming in Bhutan is beset with numerous issues and challenges. Among them, climate change is likely to pose the greatest challenge. Ecologically, farming in high elevation environments is unsustainable and more challenging due to large fluctuations and weather swings over the altitudinal gradient [62]. Farming in Bhutan is also limited by the rough topography, and farmlands are scattered in a characteristically fragmented parcels on mountainous slopes and river valleys. These conditions make farm mechanization challenging and increase cost of crop production. The same condition also makes development of irrigation and other modern farm structures very difficult. Farmlands are increasingly being left fallow, which could be attributed to increasing crop depredation by wildlife and yield reduction. Agriculture statistics of 2016 reveal $39 \%$ and $10 \%$ of the potential dryland and wetland, respectively, were left fallow in 2016 [3]. Such issues have likely contributed to rural-urban migration. Similar issues have been reported in Senegal where falling agricultural productivity was related to the exodus of people from farms to the urban centres [63]. Another very important issue is that of invasive weed species. It has been observed and reported that alien weed species, such as Lantana camara, Parthenium and Eupatorium, to name few, have started their spread into both cultivated and forested areas. Farmers have already observed colonization of their pasture lands by invasive weed species that greatly reduce regeneration capacity of grass species [64].

\section{Contributions by government agencies}

While the three RNR sectors hold direct responsibility for the food security and livelihood of the Bhutanese people, there are other government agencies supporting the DoA's strategies to combat impacts of climate change in agriculture. The College of Natural Resources (CNR) under the Royal University of Bhutan, Ugyen Wangchuck Institute for Conservation and Environmental Research (UWICE) under the Ministry of Agriculture and Forests, Department of Disaster Management (DDM) under the Ministry of Home and Cultural Affairs and the National Center for Hydrology and Meteorology (NCHM) under the Ministry of Economic Affairs are some of the agencies that play increasingly important roles in the conservation, management and research on environment and climate change. The CNR, as an academic institution, provides a broad-based study programme in the management of natural resources through inclusion of environmental studies as a core subject in its curriculum and research [65]. The UWICE is another pioneer institute that focuses on the training, education and capacity building matters related to forest science and technology, water resources, climate and conservation biology including socio-economic and policy sciences. The NCHM is mandated to provide all information on hydro-meteorological and cryosphere information, such as climate and weather forecasting services. Climate change-related disaster mitigation and management services are also supported by the DDM which is the coordinating agency for disaster and risk issues in the country [66]. While these agencies support environment protection and management to mitigate the impacts of climate change, the NEC is an independent apex body mandated to coordinate and regulate all matters related to conservation and protection of the environment [67]. It reviews environmental policies and plays an important role in improving the food security, health and environmental well-being of the country.

\section{Recommendations for climate change adaption}

Promotion of modern high-yielding crop varieties across ecologies is one of the short-term measures to adapt to the impacts of climate change. Varieties that could tolerate both biotic and abiotic stresses, such as drought, heat, diseases and pests, must be made available and promoted. With monsoon becoming more and more erratic and given short crop-growing window period for Bhutan, short-duration varieties of crops must be promoted. Short-duration crops are also a best bet for crop intensification programme, and for this, continuity in research and extension will be crucial. Given the seasonality of streams and spring waters, a major focus in building climate resilient irrigation structures and improvements in water management practices remains crucial. These interventions would likely help in sustainably improving the farm productivity. A recent study in Bangladesh revealed that adoption of climate smart agriculture has improved the food security of the coastal farmers [68]. 
To overcome crop losses, post-harvest and value addition must be given due importance. Post-harvest and storage is one of the areas requiring attention of the policy makers to protect the farmers through buffering from climatic shocks. Effective extension system and advocacy programme on climate resilient farming practices, such as alternate wetting and drying (AWD) and direct seeding in rice, are better options to overcome irrigation water issues. Such practices also have potential to reduce emission of methane from the rice fields. Further, the NCHM and DoA must enhance collaborations to improve weather information and forecasting system in order to avert crop losses resulting from extreme weather events.

For the long-term adaptation, there is a need to make adjustments in crops based on suitability across agroecologies. This should be backed by sustainable farming approaches, such as organic principles, and maintaining agrobiodiversity across the farm level. For enhancing resilience of crops, specially the fruit orchards, to the weather events, plantation of wind breaks and fodder trees is highly recommended. Further, there should be targeted research on exploring possibilities of introducing crops to non-traditional areas, such as alpine meadows and high land pastures, to exploit suitability gains from climate change. For biotic and abiotic stress, breeding of suitable varieties should be continued with suffcient financial and policy support. Likewise, the DoA, in close coordination with the DDM, must come up with a sound sustainable crop insurance policy and contingency plans to protect farmers during disasters. In order to protect and for the sustainability of agriculture, Bhutan would also require an effective policy to protect agricultural land. All such interventions must be backed by increased investments in critical areas of farming.

\section{Conclusion}

Agriculture is the mainstay of Bhutan that employs $57.20 \%$ of the Bhutanese people. However, it is faced with numerous issues and challenges, among which the impacts of climate change are considered as the most serious threat. Global warming-induced climate change impacts have already been felt, and it is likely to intensify in the near future. The vulnerability of Bhutan's agriculture has been showcased during recent major extreme weather events, such as the increased frequency of wind and hail storms, erratic rains, glacier outburst floods and appearances of new diseases and pests. The topographic feature of the country further makes farmers more vulnerable to climate change impacts, thus contributing to the subsistence nature of farming, which is highly prone to any natural calamities and disasters. Therefore, there is a need to enhance resilience of Bhutan's farming to the impacts of climate change through stepped-up cross-sectoral strategic options like policy support, enhanced investment, $R \& D$ and technology generation.

\section{Abbreviations \\ AWD: alternate wetting and drying; $\mathrm{CO}_{2}$ : carbon dioxide; $\mathrm{CNR}$ : College of Natural Resources; DoA: Department of Agriculture; DDM: Department of Disaster Management; GLOF: glacier lake outburst floods; HLB: Huanglong- bing; ICIMOD: International Centre for Integrated Mountain Development; IPCC: Intergovernmental Panel on Climate Change; MoA: Ministry of Agricul- ture; MoAF: Ministry of Agriculture and Forests; NCHM: National Centre for Hydrology and Meteorology; NEC: National Environment Commission; RCP: representative concentration pathways; RNR: renewable natural resources; RUB: Royal Government of Bhutan; UWICE: Ugyen Wangchuck Institute for Conservation and Environmental Research.}

\section{Authors' contributions}

The research was conducted by Ngawang Chhogyel as part of his Ph.D. thesis, under the guidance of Professor Lalit Kumar, who contributed ideas and reviewed the drafts thoroughly. Both authors read and approved the final manuscript.

\section{Author details \\ ${ }^{1}$ University of New England, Armidale, NSW, Australia. ${ }^{2}$ ARDC-Bajo, Depart- ment of Agriculture, Ministry of Agriculture and Forests (MoAF), Bajo, Bhutan.}

\section{Acknowledgements}

The authors thank the University of New England, Armidale, NSW, Australia, for providing scholarship for the Ph.D. programme. Gratitude is also extended to the Department of Agriculture, MoAF, Royal Government of Bhutan, for granting study leave to the senior author without which this study would not be possible.

\section{Competing interests}

The authors declare that they have no competing interests.

\section{Availability of data and materials}

All data generated and analysed during this study are included in this published article.

\section{Consent for publication}

Not applicable.

Ethics approval and consent to participate Not applicable.

\section{Funding}

The authors declare that they have not used any funds for writing this article. However, special references have been made under the acknowledgement section.

\section{Publisher's Note}

Springer Nature remains neutral with regard to jurisdictional claims in published maps and institutional affiliations.

Received: 21 August 2018 Accepted: 17 October 2018

Published online: 01 November 2018

\section{References}

1. MoLHR. Labour force survey report 2016. Bhutan: Labour Market Information and Research Division, Department of Employment and Human Resources: 2016

2. NSB. National accounts statistics 2017. Thimphu: National Statistics Bureau (NSB), Royal Government of Bhutan; 2017. 
3. DoA. Agriculture statistics 2016. Thimphu: Information Management Section (IMS), Department of Agriculture, Ministry of Agriculture and Forests, Royal Government of Bhutan; 2016.

4. PPD. Bhutan RNR statistics 2015. Thimphu: Policy and Planning Division (PPD) of the Ministry of Agriculture and Forests, Royal Government of Bhutan, Thimphu; 2015.

5. NSSC, PPD. Bhutan land cover assessment 2010 — technical report. Thimphu: NSSC and PPD, Ministry of Agriculture and Forests; 2011.

6. IPCC. Climate change 2001: impacts, adaptation and vulnerability. Technical report. Intergovernmental Panel on Climate Change (IPCC), UNEP. Report no.: II. Cambridge: Cambridge University Press; 2001.

7. Gornall J, Betts R, Burke E, Clark R, Camp J, Willett K, et al. Implications of climate change for agricultural productivity in the early twenty-first century. Philos Trans R Soc Lond B Biol Sci. 2010;365(1554):2973-89. https ://doi.org/10.1098/rstb.2010.0158.

8. Yohannes $\mathrm{H}$. A review on relationship between climate change and agriculture. J Earth Sci Clim Change. 2015;7(2):335. https://doi. org/10.4172/2157-7617.1000335.

9. Jiro K, Toru K, Tsutomu Y, Tshering P. Glacial lake outburst events in the bhutan himalayas. Glob Environ Res. 2012;16:59-70.

10. PPD. Bhutan RNR statistics 2016. Thimphu: Policy and Planning Division (PPD) of the Ministry of Agriculture, Royal Government of Bhutan; 2016.

11. SNV, DoA. Climate smart agriculture, source book. Thimphu: Netherlands Development Organization (SNV) and Department of Agriculture, MoAF; 2015.

12. IPCC. Climate change 2013: the physical science basis. Contribution of the working group I to the fifth assessment report of the Intergovernmental Panel on Climate Change. Cambridge, New York: Cambridge University Press; 2013.

13. NEC. Second national communication to the UNFCCC. Thimphu: National Environment Commission (NEC), Ministry of Agriculture, Royal Government of Bhutan; 2011.

14. NEC. Bhutan national adaptation programme of actions. Thimphu: National Environment Commission (NEC) under the Ministry of Agriculture and Forests, Royal Government of Bhutan; 2006.

15. MoA. National research programme. In: Ministry of Agriculture (MoA). Royal Government of Bhutan, Thimphu; 1992

16. IPCC. Climate change 2007: impacts, adaptation and vulnerability. Contribution of working group II to the fourth assessment report of the intergovernmental panel on climate change. Cambridge: Cambridge University Press; 2007.

17. Parker L, Guerten N, Nguyen TT, Rinzin C, Tashi D, Wangchuk D, et al. Climate change impacts in Bhutan: challenges and opportunities for the agriculture sector. Working paper No.191. Wageningen: CGIAR research programme on climate change, Agriculture and Food Security (CCAFS); 2017. Contract No.: 191; https://doi.org/10.7910/dvn/hgecwu.

18. ICIMOD. Climate change vulnerability of mountain ecosystems in the Eastern Himalayas: climate change impact and vulnerability in the Eastern Himalayas-Synthesis report. Kathmandu: International Centre for Integrated Mountain Development (ICIMOD); 2010.

19. Bajracharya SR, Maharjan SB, Shrestha F. The status and decadal change of glaciers in Bhutan from the 1980s to 2010 based on satellite data. Ann Glaciol. 2017:55(66):159-66.

20. Bates B, Kundzewicz ZW, Wu S, Palutikof J. Climate change and water. Technical paper of the Intergovernmental Panel on Climate Change. Geneva: IPCC Secretariat; 2008.

21. Durand $Y$, Giraud $G$, Laternser $M$, Etchevers $P$, Mérindol L, Lesaffre B. Reanalysis of 47 years of climate in the French alps (1958-2005): climatology and trends for snow cover. J Appl Meteorol Climatol. 2009;48(12):2487512. https://doi.org/10.1175/2009JAMC1810.1.

22. Beniston M, Farinotti D, Stoffel M, Andreassen LM, Coppola E, Eckert N, et al. The European mountain cryosphere: a review of its current state, trends, and future challenges. The Cryosphere. 2018;12(2):759-94. https:// doi.org/10.5194/tc-12-759-2018

23. Rupper S, Schaefer JM, Burgener LK, Koenig LS, Tsering K, Cook ER. Sensitivity and response of Bhutanese glaciers to atmospheric warming. Geophys Res Lett. 2012. https://doi.org/10.1029/2012GL053010.

24. Gorsuch J. Local tradition meets modern know-how. Los Banos: International Rice Research Institute (IRRI); 2001.

25. Shrestha S, Dukpa D, Pulami T, wangdi K, Drukpa W, Dem P. An economic impact assessment of the rice research program in Bhutan.
Report. International Rice Research Institute (IRRI). Los Baños: International Rice Research Institute (IRRI); 2004.

26. Shrestha MS, Goodrich CG, Udas P, Rai DM, Gurung MB, Khadgi V. Flood early warning systems in Bhutan: a gendered perspective. Kathmandu: International Centre for Integrated Mountain Development (ICIMOD); 2016.

27. NSB. Statistical year book of Bhutan 2017. Thimphu: National Statistical Bureau (NSB), Royal Government of Bhutan; 2017.

28. DoA. Agriculture land development guidelines (ALDG). Thimphu: Department of Agriculture, Ministry of Agriculture and Forests, Royal Government of Bhutan; 2017.

29. PPD. RNR sector eleventh five year plan 2013-2018. Thimphu: Policy and Planning Division (PPD), MInistry of Agriculture and Forests, Royal Government of Bhutan; 2014

30. Chhogyel N, Ghimiray M. Food policy in Bhutan. Reference module in food science; 2017. p. 1-11. https://doi.org/10.1016/B978-08-10059 6-5.21888-X

31. Katwal T, Dorji S, Dorji R, Tshering L, Ghimiray M, Chhetri G, et al. Community perspectives on the on-farm diversity of six major cereals and climate change in Bhutan. Agriculture. 2015;5(1):2-16. https://doi. org/10.3390/agriculture5010002.

32. Katwal TB. Popularizing multiple cropping innovation as a means to raise crop productivity and farm income in Bhutan. Popularizing multiple cropping innovation as a means to raise crop productivity and farm income. Dhaka: SAARC Agriculture Centre (SAC); 2013. p. 35-63.

33. Mamun SA, Nusrat F, Debi MR. Integrated faring system in Bangladesh: prospects in Bangladesh. J Environ Sci Nat Resour. 2011;4(2):127-36. https://doi.org/10.3329/jesnr.v4i2.10161.

34. ADB. Climate change country risk assessment. report. Report No.: 2014-2018. Manila: Asian Development Bank (ADB); 2014.

35. Norbu C. Environment: global warming is a realty. How is it affecting Bhutan? Some field observations. Sonam Drupdrey, Annual RNR Magazine; 2016. p. 29-30.

36. MoAF. National action plan biodiversity persistence and climate change-a country report for Bhutan Climate Change submit. Thimphu: Ministry of Agriculture and Forests (MoAF), Royal Goverment of Bhutan; 2011.

37. DoA. Agriculture statistics 2016. Thimphu: Department of Agriculture (DoA), Ministry of Agriculture and Forests, Royal Government of Bhu$\tan ; 2016$.

38. Bouman B, Lampayan R, Tuong T. Water management in irrigated rice: coping with water scarcity. Los Banos: International Rice Research Institute (IRRI); 2007.

39. GRiSP. Rice almanac. 4th ed. Los Banos: International Rice Institute (IRRI); 2013.

40. Wiltshire A. Climate change implications for the glaciers of the Hindu Kush, Karakoram and Himalayan region. The Cryosphere. 2014;8(3):941-58. https://doi.org/10.5194/tc-8-941-2014.

41. Dorji U, Olesen JE, Bøcher PK, Seidenkrantz MS. Spatial variation of temperature and precipitation in Bhutan and links to vegetation and land cover. Mountain Res Dev. 2016;36(1):66-79. https://doi. org/10.1659/MRD-JOURNAL-D-15-00020.1.

42. Javier EL. A review of Bhutan's rice research programme with emphasis on the low altitude zone. In: Council of Renewable Natural Resoruces Research of Bhutan, Thimphu; 2007.

43. Chhogyel N, Ghimiray M, Subedi K. Crop suitability modelling for rice under future climate scenario in Bhutan. Bhutanese J Agric. 2018;1(1):49-57.

44. Wu Y-C, Chang S-J, Lur H-S. Effects of field high temperature on grain yield and quality of a subtropical type japonica rice-Pon-Lai rice. Plant Prod Sci. 2016;19(1):145-53. https://doi.org/10.1080/13439 43X.2015.1128091.

45. Jagadish SV, Craufurd PQ, Wheeler TR. High temperature stress and spikelet fertility in rice (Oryza sativa L.). J Exp Bot. 2007;58(7):1627-35. https://doi.org/10.1093/jxb/erm003.

46. Ismail N, Hossain K, Quaik S, Rafatullah M, Ali I, Hatta ZA, et al. Climate change-perceived impacts on agriculture, vulnerability and response strategies for improving adaptation practice in developing countries (South Asian region). Int J Agric Res. 2016;11(1):1-12. https://doi. org/10.3923/ijar.2016.1.12. 
47. Gérardeaux E, Sultan B, Palaï O, Guiziou C, Oettli P, Naudin K. Positive effect of climate change on cotton in 2050 by $\mathrm{CO}_{2}$ enrichment and conservation agriculture in Cameroon. Agron Sustain Dev. 2012;33(3):485-95. https://doi.org/10.1007/s13593-012-0119-4.

48. Ackerman F, Munitz C. A critique of climate damage modeling: carbon fertilization, adaptation, and the limits of FUND. Energy Res Soc Sci. 2016;12:62-7. https://doi.org/10.1016/j.erss.2015.11.008.

49. Tubiello FN, Rosenzweig C, Goldberg RA, Jagtap S, Jones JW. Effect of climate change on US crop production: simulation results using two different GCM scenarios. Part I: wheat, potato, maize and citrus. Clim Res. 2002;20:259-70. https://doi.org/10.3354/cr020259.

50. Lobell DB, Field CB. Global scale climate-crop yield relationships and the impacts of recent warming. Environ Res Lett. 2007;2(1):014002. https:// doi.org/10.1088/1748-9326/2/1/014002.

51. Maracchi G, Sirotenko O, Bindi M. Impacts of present and future climate variability on agriculture and forestry in the temperate regions: Europe. Clim Change. 2005;70(1-2):117-35.

52. Tshewang S, Park RF, Chauhan BS, Joshi AK. Challenges and prospects of wheat production in Bhutan: a review. Exp Agric. 2017;54:1-15. https:// doi.org/10.1017/s001447971700014X

53. DoA. Agriculture statistics 2015. Thimphu: Department of Agriculture, Ministry of Agriculture and Forests, Royal Government of Bhutan; 2015.

54. Donovan NJ, Beattie GAC, Chambers GA, Holford P, Englezou A, Hardy S, et al. First report of 'Candidatus Liberibacter asiaticus' in Diaphorina communis. Australas Plant Dis Notes. 2011;7(1):1-4.

55. Dorji K, Lakey L, Chophel S, Dorji SD, Tamang B. Adoption of improved citrus orchard management practices: a micro study from Drujegang growers, Dagana, Bhutan. Agric Food Secur. 2016;5(1):3. https://doi. org/10.1186/s40066-016-0050-z.

56. Dorji P. Deciduous fruit production in Bhutan. Deciduous fruit production in Asia and the Pacific; 1999. p 18.

57. Ames GK, Dufour R. Climate change and perennial fruit and nut production: investing in resilience in uncertain times. National Center for Appropriate Technology Retrieved July. 2014; 15:2016.
58. Bal S, Minhas P, Singh Y, Kumar M, Patel D, Rane J, et al. Coping with hailstorm in vulnerable deccan plateau region of India: technological interventions for crop recovery. Curr Sci. 2017;113(10):2012-27. https:// doi.org/10.18520/cs/v113/i10/2021-2027.

59. Albrigo L, Buker R, Burns J, Castle W, Futch S, McCoy C, et al., editors. The impacts of four hurricanes in 2004 on the Florida citrus industry: experiences and lessons learned. In: Proceedings of the Florida state horticulture society. University of Florida: Citrus Research and Education Center, Horticultural Sciences of the University of Florida; 2005.

60. Ramirez F, Kallarackal J. Response of fruit trees to global climate change. Berlin: Springer; 2015.

61. Luedeling E, Girvetz EH, Semenov MA, Brown PH. Climate change affects winter chill for temperate fruit and nut trees. PLoS ONE. 2011;6(5):e20155. https://doi.org/10.1371/journal.pone.0020155.

62. Chapin FS, Sturm M, Serreze M, McFadden J, Key J, Lloyd A, et al. Role of land-surface changes in Arctic summer warming. Science. 2005;310(5748):657-60.

63. Goldsmith PD, Gunjal K, Ndarishikanye B. Rural-urban migration and agricultural productivity: the case of Senegal. Agric Econ. 2004;31(1):33-45.

64. Suberi B, Tiwari K, Gurung D, Bajracharya R, Sitaula B. People's perception of climate change impacts and their adaptation practices in Khotokha valley, Wangdue Bhutan. Indian J Tradit Knowl. 2018;17(1):97-105.

65. RUB. Programmes of study. Thimphu: The Royal University of Bhutan; 2013.

66. DDM. Disaster risk management strategy. Safe, resilient and happy Bhutan. Thimphu: Department of Disaster Management (DDM), Ministry of Home and Cultural Affairs, Royal Government of Bhutan; 2013.

67. NEC. Environment assessment act, 2000. Thimphu: National Environment Commission (NEC), Royal Government of Bhutan; 2000.

68. Hasan MK, Desiere S, D'Haese M, Kumar L. Impact of climate-smart agriculture adoption on the food security of coastal farmers in Bangladesh. Food Secur. 2018;10(4):1073-88. https://doi.org/10.1007/s1257 1-018-0824-1.
Ready to submit your research? Choose BMC and benefit from:

- fast, convenient online submission

- thorough peer review by experienced researchers in your field

- rapid publication on acceptance

- support for research data, including large and complex data types

- gold Open Access which fosters wider collaboration and increased citations

- maximum visibility for your research: over $100 \mathrm{M}$ website views per year

At $\mathrm{BMC}$, research is always in progress.

Learn more biomedcentral.com/submissions 